\title{
In Vitro Bioaccessibility of the Vitamin B Series from Thermally Processed Leafy African Indigenous Vegetables
}

\author{
Zipporah M. Onyambu $\mathbb{D}^{1},{ }^{1}$ Mildred P. Nawiri, ${ }^{2}$ Hudson N. Nyambaka $\mathbb{D}^{2}$, \\ and Naumih M. Noah iD ${ }^{3}$ \\ ${ }^{1}$ Department of Chemistry and Biochemistry, University of Eldoret, P.O. Box 1125-30100, Eldoret, Kenya \\ ${ }^{2}$ Department of Chemistry, Kenyatta University, P.O. Box 43844-00100, Nairobi, Kenya \\ ${ }^{3}$ School of Pharmacy and Health Sciences, United States International University-Africa (USIU-Africa), P.O. Box 14634-00800, \\ Nairobi, Kenya
}

Correspondence should be addressed to Zipporah M. Onyambu; zipporah.moraa@uoeld.ac.ke

Received 15 February 2021; Revised 14 June 2021; Accepted 21 June 2021; Published 28 June 2021

Academic Editor: Nasim Ahmad Yasin

Copyright ( 2021 Zipporah M. Onyambu et al. This is an open access article distributed under the Creative Commons Attribution License, which permits unrestricted use, distribution, and reproduction in any medium, provided the original work is properly cited.

\begin{abstract}
Thermal processing of leafy African indigenous vegetables (LAIVs), which are rich in nutrients, especially vitamin B series affects the levels and bioaccessibility of the vitamins. This study investigated the bioaccessibility of vitamin B series in fresh and thermally processed LAIVs. Five commonly consumed indigenous vegetables, Cleome gynadra, Vigna unguilata, Amaranthus viridis, Basella alba, and Cucurbita maxima, were processed by boiling and/or frying, treated to in vitro gastrointestinal digestion procedure, and levels of vitamin B series determined before and after treatment. The vitamin B series in fresh LAIVs ranged from $0.73 \pm 0.01 \mathrm{mg} /$ $100 \mathrm{~g}\left(\mathrm{~B}_{9}\right.$; spider plant) to $174.16 \pm 3.50 \mathrm{mg} / 100 \mathrm{~g}\left(\mathrm{~B}_{2}\right.$; vine spinach) and had both significant increase (ranging from $+8.71 \%$ to $+446.84 \%$ ) and decrease (ranging from $-0.44 \%$ to $-100.00 \%)$ with thermal processing $(p<0.001)$. The in vitro digestion resulted in a significant increase $(p<0.001)$ of vitamins ranging from $5.18 \%\left(B_{5}\right.$; boiled cowpeas) to $100 \%\left(B_{2}, B_{3}\right.$, and $B_{6}$ in several processed vegetables). Where detected, the bioaccessible levels of vitamin B series in fresh, processed, and in vitro digested samples were sufficient to meet the Recommended Dietary Allowances (RDA) of children and adults. These findings support the promotion of a nutritional approach to malnutrition resulting from vitamin B series deficiency.
\end{abstract}

\section{Introduction}

Vitamins are a group of organic compounds which are important for the normal functioning of the body $[1,2]$. Vitamin $B$, a series of vitamins, namely, thiamin $\left(B_{1}\right)$, riboflavin $\left(B_{2}\right)$, niacin $\left(B_{3}\right)$, pantothenic acid $\left(B_{5}\right)$, pyridoxine $\left(\mathrm{B}_{6}\right)$, and folate $\left(\mathrm{B}_{9}\right)$, are water-soluble and are found majorly in leafy African indigenous vegetables (LAIVs) and fruits. They play key roles in cellular metabolism and homeostasis, maintenance of healthy skin and muscle tone, enhancing immune and nervous function, and promoting healthy cell division and hematopoietic activity [3]. Consistent consumption of diets rich in these vitamins not only maintains good health but also addresses malnutrition $[4,5]$. The recommended dietary allowances (RDAs) for the vitamin B series range from $0.1-20 \mathrm{mg} /$ day [6].

Malnutrition affects more than two billion people globally [1], although it is more alarming in developing countries where young women and children are mostly affected [7]. The result of malnutrition is poor health, low worker productivity, high mortality rate, and morbidity [1]. The deficiency of vitamins $B_{1}, B_{2}, B_{3}, B_{5}, B_{6}$, and $B_{9}$ causes beriberi, cardiac disorder, pellagra, impaired coordination, neurological disturbances, and megaloblastic anemia, respectively [8]. Malnutrition is mainly addressed through the nutritional approach, supplementation, and food fortification $[8,9]$. Consumption of LAIVs as a nutritional approach is promoted because they are rich sources of not only vi- 
tamin B series but also other vitamins, minerals, and other phytochemicals [8]. Alam et al. [10], for instance, reported levels of vitamin $B\left(B_{1}, B_{2}, B_{3}\right.$, and $\left.B_{6}\right)$ in unconventional leafy and nonleafy vegetables ranging from $0.06 \pm 0.01$ to $1.05 \pm 0.13 \mathrm{mg} / 100 \mathrm{~g}$ and recommended that regular intake of the vegetables would help combat micronutrient deficiency.

There are more than 200 species of LAIVs in Kenya cultivated by over $60 \%$ of households in the rural and periurban parts of Kenya [11, 12]. Spider plant (Cleome gynandra), cowpeas (Vigna unguiculata), vegetable amaranth (Amaranthus viridis), vine spinach (Basella alba), and vegetable pumpkin (Cucurbita maxima) are among the common LAIVs in Western Kenya [13]. Cultivated by smallholders, the vegetables are commonly consumed due to their medicinal value, such as antibacterial and antioxidant properties, and rich micronutrient such as vitamins and microelements [14]. This makes them not only generally available but also inexpensive, although a number of them are unfortunately underutilized and unconsumed [15]. In addition to being promoted to address malnutrition, the LAIVs are a source of income for small-scale farmers $[16,17]$.

Vegetables are commonly processed, mainly by boiling, frying, and steaming $[11,18,19]$. However, thermal processing affects the levels of vitamins, though the process is necessary since it releases vitamins from the vegetable matrix [20]. Cooking water has been reported to reduce levels of thiamin by between $31 \%$ and $50 \%$, riboflavin by $50 \%$, and niacin by $80 \%[21,22]$. Factors that enhance the loss of vitamin $B$ series in heat processing include the presence of water, oxygen, light, and $\mathrm{pH}[3,8,21,23,24]$. These watersoluble vitamins are extractable into water (leaching) during blanching and cooking [21]. Oxidative cleaving is usually minimized during cooking by steaming the vegetables until the pathway between tender and crisp [3, 24]. Pantothenic acid is stable to heat at a $\mathrm{pH}$ of $5-7$, although it can be lost during cooking [23].

Vitamins in vegetables are complexed in the nutrient matrix, requiring their breakdown to make them bioaccessible for absorption. Bioaccessibility, the amount of ingested nutrients that potentially become available for absorption in the gastrointestinal tract [25], is affected by food matrix, processing, interaction with other dietary compounds, and physicochemical properties [26, 27]. High dietary fiber in vegetables decreases the bioaccessibility of nutrients by slowing gastric emptying, digestion, and absorption of nutrients, mainly due to the water retained by pectin that forms a viscous solution in the gut [28-31]. Thermal processing is important in increasing the surface area and the interaction of hydrolytic enzymes and emulsifiers with food particles during the gastric and intestinal phases of digestion to release nutrients [28, 29, 31]. However, the released vitamin may undergo a chemical reaction due to $\mathrm{pH}$ change or from the oxidative reaction, as seen in betacarotene in thermally processed LAIVs [32].
Studies of in vitro bioaccessibility using the gastrointestinal model can determine the digestibility of the food material, the fraction of food components that are transformed into potentially accessible matter through physical and chemical processes occurring in the ileum $[25,33]$ and inform the best food processing procedures that retain high levels of nutrients. There is little information on the bioaccessibility of vitamin B series from thermally processed LAIVs, which are important in addressing vitamin B deficiency. Hence, an in vitro method of digestion was employed to study the bioaccessibility of vitamin B series from thermally processed (boiled and boiled-fried) spider plant, cowpeas, amaranth, vine spinach, and pumpkin leaves.

\section{Materials and Methods}

2.1. Equipment and Chemicals. High-Performance Liquid Chromatography (HPLC), (Shimadzu SPD 20A) equipped with a photodiode array detector (PDA) and an autosampler was used to quantify the vitamins. The separation was achieved using a reversed-phase C-18 column $(250 \mathrm{~mm} \times 2 \mathrm{~mm}$ i.d, $5 \mu \mathrm{m})$ manufactured by Hamilton Company. The mobile phase used was potassium dihydrogen phosphate and methanol in the ratio of $90: 10$. All chemicals and reagents used were of analytical grade, and methanol was HPLC grade. The standards thiamin, riboflavin, niacin, pantothenic acid, pyridoxine, and folic acid were purchased from SigmaAldrich. Sep-Pak C18 (500 mg) cartridge from Sigma-Aldrich was used for precolumn separation.

The stock solutions of vitamin $\mathrm{B}_{1}, \mathrm{~B}_{2}, \mathrm{~B}_{3}, \mathrm{~B}_{5}, \mathrm{~B}_{6}$, and $\mathrm{B}_{9}$ were prepared by dissolving $0.01 \mathrm{~g}$ of each standard in $50 \mathrm{ml}$ of $0.1 \mathrm{~m} \mathrm{HCl}$ in a $100 \mathrm{ml}$ volumetric flask and diluted to the mark. Following appropriate dilutions using $0.1 \mathrm{~m} \mathrm{HCl}$, serial standards were prepared in the following ranges in ppm; $\mathrm{B}_{1}(0-10), \mathrm{B}_{2}(0-10), \mathrm{B}_{3}(0-8), \mathrm{B}_{5}(0-8), \mathrm{B}_{6}(0-8)$, and $\mathrm{B}_{9}(0-8)$ then filtered using $0.45 \mu \mathrm{m}$. A calibration line was obtained by plotting the peak area values as a function of the concentration of the vitamin.

The LoDs, regression equations, and correlation coefficients are presented in Table 1.

The LoDs ranged from 0.02 to 0.12 and this is comparable to that reported by Cheruiyot [34] (0.03 to 0.17$)$. The correlation coefficient values were above 0.9736 , indicating at least a $97.36 \%$ relationship of absorbance against concentration, thus implying linearity [35]. The percentage recoveries were between $98.96 \pm 0.15$ and $101.27 \%$ implying that the methods had a conventionally acceptable precision and accuracy [36].

2.2. Sample Preparation. Five leafy vegetables cultivated in Africa samples, spider plant (Cleome gynadra), cowpeas (Vigna unguiculata), amaranth (Amaranthus blitum), vine spinach (Basella alba), and pumpkin leaves (Cucurbita maxima), were collected from an open market in Kisii County, Kenya in September (wet season). Kisii County is a 
TABLE 1: Method validation parameters of vitamin B series.

\begin{tabular}{lcccc}
\hline Vitamins & LoD & Correlation coefficient & Regression equation & $\%$ recovery \\
\hline Thiamin & 0.12 & 0.9783 & $y=36499 x-2346.8$ & $101.27 \pm 1.27$ \\
Riboflavin & 0.04 & 0.9998 & $y=49440 x-496.57$ & $99.13 \pm 0.47$ \\
Niacin & 0.08 & 1 & $y=9441 x-72.8$ & $100.37 \pm 0.38$ \\
Pantothenic acid & 0.10 & 0.9736 & $y=2203.8 x+547.67$ & $100.18 \pm 0.16$ \\
Pyridoxine & 0.03 & 0.9960 & $y=14982 x-2931.8$ & $99.74 \pm 1.38$ \\
Folate & 0.03 & 0.9960 & $y=49747 x+132.5$ & $100.35 \pm 0.35$ \\
\hline
\end{tabular}

major grown region in western Kenya [13] and sampling was done in Kisii Town because leafy African indigenous vegetables (LAIVs) from many planting areas in the County are brought there for sale since the town is central and has a large population. The LAIVs were purchased randomly from several venders and mixed to give $1 \mathrm{~kg}$ of each vegetable, and immediately sprayed with water to keep them moistened, packed in dark plastic polythene bags, and transported to the Department of Food Science and Technology laboratory, Jomo Kenyatta University of Agriculture and Technology (JKUAT) for analysis.

The vegetables were trimmed to remove inedible parts, washed under tap water, rinsed with distilled water, and flapped to remove water. Pumpkin leaves (Cucurbita maxima), which had broad leaves, were cut into small pieces after washing. Each vegetable type was divided into 2 portions, with the first portion of about $100 \mathrm{~g}$ used for fresh analysis and the second portion boiled. To prepare the boiled samples, $80 \mathrm{~g}$ of the fresh vegetables were boiled in $200 \mathrm{ml}$ of distilled water for 10 minutes at $100^{\circ} \mathrm{C}$ and then cooled to room temperature. For the fried samples, $40 \mathrm{~g}$ of boiled vegetables were added to $40 \mathrm{ml}$ of vegetable oil already heated in a cooking pan $\left(100^{\circ} \mathrm{C}\right)$. This was fried for 10 minutes and then cooled to room temperature. The fresh, boiled, and boiled-fried samples were placed in zip-locked bags, frozen for five hours at $-20^{\circ} \mathrm{C}$, and then freeze-dried at $-50^{\circ} \mathrm{C}$ for 96 hours. The freeze-dried samples were then wrapped in aluminum foil and kept in the refrigerator at $4^{\circ} \mathrm{C}$ awaiting determination of vitamin B series.

2.3. Extraction and Measurement of Vitamin B Series. Extraction of vitamin B series was performed according to [37]. To $5 \mathrm{~g}$ of each vegetable sample, $20 \mathrm{~mL}$ of deionized water was added and the mixture homogenized at medium speed for 1 minute before centrifuging for 10 minutes at $14 \times 103 \mathrm{~g}$ (Sigma, Bio Block Scientific 2-16). A sample $(10 \mathrm{~mL})$ of the supernatant was then loaded to a Sep Pak C18 cartridge, flushed with $10 \mathrm{~mL}$ methanol and $10 \mathrm{~mL}$ water adjusted to $\mathrm{pH} 4.2$, and was eluted with $5 \mathrm{~mL}$ acidified water, $\mathrm{pH} 4.2$ (prepared by adding $0.005 \mathrm{~m} \mathrm{HCl}$ ) followed by $10 \mathrm{~mL}$ methanol at a flow rate of $1 \mathrm{~mL} / \mathrm{min}$. The eluent was collected in a bottle and evaporated to dryness, and then reconstituted using the mobile phase. Before HPLC analysis, all samples were filtered through $0.45 \mu \mathrm{m}$ pore size (FP 30/45 CA-S filters, Schleicher and Schuell, Darmstadt, Germany) at 7 bar max. $20 \mu \mathrm{L}$ of each sample solution was injected into the HPLC column by an autosampler.
The accuracy of HPLC was investigated by spiking samples with a known amount of standards. Analysis was performed thrice. The analysis of the samples was done simultaneously for thiamin $\left(B_{1}\right)$, niacin $\left(B_{3}\right)$, pantothenic acid $\left(\mathrm{B}_{5}\right)$, pyridoxine $\left(\mathrm{B}_{6}\right)$, and folate $\left(\mathrm{B}_{9}\right)$ using the mobile phase $0.1 \mathrm{~mol} / \mathrm{L} \mathrm{KH}_{2} \mathrm{PO}_{4}(\mathrm{pH} 7)$ and methanol $(90: 10)$ as reported by Ekinci and Kadakal, while riboflavin $\left(\mathrm{B}_{2}\right)$ was analyzed separately. The column elute was monitored with a photodiode array (PDA) detector for thiamin $(234 \mathrm{~nm})$, riboflavin $(266 \mathrm{~nm})$, niacin $(261 \mathrm{~nm})$, pantothenic acid $(204 \mathrm{~nm})$, pyridoxine $(324 \mathrm{~nm})$, and folic acid $(282 \mathrm{~nm})$. The mobile phase was filtered through a $0.45 \mu \mathrm{m}$ membrane and degassed by sonication before use. The flow rate was $1 \mathrm{~mL} /$ min and the column was operated at room temperature $\left(25^{\circ} \mathrm{C}\right)$. Chromatographic peak data were integrated for up to 39 minutes. Identification of the compounds was achieved by comparing their retention times and UV spectra with those of the standards. Calibration curves were plotted for each vitamin and the concentrations of the vitamins were calculated from the integrated areas of the sample and the corresponding standards.

\subsection{Simulated Gastrointestinal Digestion and Measurement of} Bioaccessible Vitamin B Series. The simulated in vitro digestion method was adapted from [31] and was done in triplicate. The process involved two phases: the gastric phase and intestinal phase. The sample, $2 \mathrm{~g}$, was subjected to simulated gastric digestion at $\mathrm{pH} 2.0$ in the presence of pepsin at $37^{\circ} \mathrm{C}(16 \mathrm{~g}$ in $100 \mathrm{~mL} 0.1 \mathrm{~m} \mathrm{HCl})$ for $2 \mathrm{hrs}$, followed by digestion in the presence of pancreatin-bile extract mixture (4 $\mathrm{g}$ porcine pancreatin) and $25 \mathrm{~g}$ of bile extract (porcine) in $1000 \mathrm{ml}$ of $0.1 \mathrm{~m} \mathrm{NaHCO}_{3} \mathrm{pH} 7.5$ at $37^{\circ} \mathrm{C}$ for $2 \mathrm{hrs}$. The micellar fraction containing the bioaccessible vitamin B was separated by ultracentrifugation at 70,000 $\times \mathrm{g}$ for 120 minutes using a Beck-man L765 ultracentrifuge. The supernatant aliquot was filtered using a $0.22 \mu \mathrm{m}$ microfilter to obtain a micellar fraction, placed in an amber glass bottle, and the levels of vitamin B series measured as per Section 2.3. To obtain the percentage bioaccessibility (\%), the bioaccessible levels were divided by the original levels and then multiplied by one hundred.

$$
\% \text { bioaccessibility }=\frac{\text { bioaccessible levels }}{\text { original content }} \times 100 .
$$


2.5. Data Analysis. One-way ANOVA was used to compare the mean levels of vitamin B series in vegetables prepared using different thermal processes, at $p$ value $<0.05$ significant difference. Mean separations were done by the standard error [38].

\section{Results and Discussion}

The mean levels (mg/100 g DW) and bioaccessible levels (\%) of vitamin B series in fresh and processed vegetables are represented in Tables 2 and 3, respectively. The range of mean levels $(\mathrm{mg} / 100 \mathrm{~g})$ of thiamin $\left(B_{1}\right)$, riboflavin $\left(B_{2}\right)$, niacin $\left(B_{3}\right)$, pantothenic acid $\left(B_{5}\right)$, pyridoxine $\left(B_{6}\right)$, and folate $\left(B_{9}\right)$ in the fresh vegetables were as follows: $0.83 \pm 0.01$ (vine spinach) $-4.56 \pm 0.04$ (pumpkin leaves), $35.44 \pm 0.72$ (pumpkin leaves) $-174.16 \pm 3.50$ (vine spinach), $10.36 \pm 0.87$ (amaranth) $-107.70 \pm 1.80$ (spider plant), $9.45 \pm 0.20$ (cowpeas)-14.00 \pm 0.15 (pumpkin leaves), $5.88 \pm 0.30$ (spider plant) $-83.10 \pm 0.92$ (amaranth), and $0.73 \pm 0.01$ (spider plant)-20.68 \pm 0.12 (cowpeas), respectively. Fresh vegetables are known to contain different levels of vitamins, this being attributed to vegetable variety, plant age, soil, climate, loss during washing, and postharvest handling and storage [21, 39, 40]; Uraku et al.; [41]. However, the levels of some vitamins in vegetables have been documented to be lower than those reported in this study [41] and Kunyanga et al. [42] reported levels $(\mathrm{mg} / 100 \mathrm{~g})$ of vitamin $\mathrm{B}_{1}, \mathrm{~B}_{2}, \mathrm{~B}_{3}$, and $B_{9}$ in amaranth to be $0.42 \pm 0.09,0.44 \pm 0.03,0.70 \pm 0.00$, and $0.83 \pm 0.02$, respectively, while in pumpkin leaves, the levels of vitamin $B_{1}, B_{2}$, and $B_{3}$ were $0.08 \pm 0.12,0.06 \pm 0.01$, and $0.32 \pm 0.01$, respectively. The levels of vitamin $B_{1}, B_{2}$, and $\mathrm{B}_{6}$ reported by [41] in amaranth dried for two weeks were $9.731 \pm 3.250,7.161 \pm 0.521$, and $25.020 \pm 2.667$, respectively.

The levels of the vitamins in vegetables showed a significant change with thermal processing $(p<0.001)$. The levels both increased $(+11.14$ to +425.96$)$ and decreased $(-6.02$ to -100.00$)$, although the resultant levels in most processed vegetables except dried ones were found to be sufficient to meet the RDA of children and adults when the right amounts are consumed [6]. Boiling, for example, had an increase of thiamin in spider plants $(+75.64 \%)$, amaranth $(+129.52 \%)$, and vine spinach $(+28.92 \%)$, but it reduced the same vitamin in cowpeas $(-15.86 \%)$ and pumpkin leaves $(-18.42 \%)$. Drying, on the other hand, reduced the vitamin $\left(B_{1}\right)$ in all vegetables. Vitamins $B_{1}, B_{2}$, $B_{3}, B_{5}, B_{6}$, and $B_{9}$ were not detected in boiled, fried cowpeas, boiled, fried spider plant, boiled amaranth, dried pumpkin leaves, boiled vine spinach, and dried amaranth, respectively.

It was observed that specific vegetables responded differently and encountered different effects on the vitamin B series. Spider plants, for example, had the levels of $B_{1}, B_{3}$, and
$\mathrm{B}_{6}$ increasing with boiling, while vitamins $\mathrm{B}_{2}, \mathrm{~B}_{5}$, and $\mathrm{B}_{9}$ decreased. On the other hand, dried cowpeas, fried vine spinach, and dried pumpkin had levels of all the vitamins decrease. Factors including loss during washing and leaching during boiling are known to contribute to the effects of processing $[21,22,41]$. The reductions are attributed to the vitamin being water-soluble and sensitive to heat and oxidation, while the release of the vitamin from its protein matrix during cooking explains their increase $[8,20,21]$.

Following in vitro digestion of the LAIVs, the resultant mean bioaccessible levels $(\mathrm{mg} / 100 \mathrm{~g}$ ) of the vitamin B series in fresh vegetables (Table 3 ) indicated that the lowest was $0.27 \pm 0.01$ for $B_{1}$ and the highest was $174.52 \pm 3.57$ for $B_{2}$ in vine spinach. There were significant differences in the mean bioaccessible levels, dependent on the original levels in the vegetables as a result of the thermal processing of the vegetables $(p<0.001)$. The increase in the vitamins ranged from $5.18 \%\left(\mathrm{~B}_{5}\right)$ in boiled cowpeas to $100 \%\left(\mathrm{~B}_{2}, \mathrm{~B}_{3}\right.$, and $\left.\mathrm{B}_{6}\right)$ in several processed vegetables. Boiled and boiled-fried amaranth and vine spinach had undetectable levels of $B_{3}$, indicating $100 \%$ loss of the vitamin with processing ( $\mathrm{Ta}-$ ble 2). Vitamins $B_{2}$ (boiled spider plant), $B_{1}$ (boiled vine spinach), and $\mathrm{B}_{3}$ (boiled pumpkin and cowpeas), which, although increased with processing (Table 2), were undetected following the in vitro digestion. These findings underscore the fact that boiling alone does not encourage bioaccessibility despite the vegetable variety and plant age $[21,39]$.

The digestibility of the vegetables differs depending on the fiber content $[25,33]$. Dietary fiber lowers bioaccessibility by physically entrapping nutrients and enhancing the viscosity of gastric fluids, thereby restricting the mixing process [30, 43]. Results from several studies report an increase in fiber content in the order spider plant $<$ vine spinach $<$ amaranth $<$ pumpkin leaves $<$ cowpeas $[42,44-46]$. The findings show that the order of increasing fiber content did not necessarily have a decrease in the bioaccessibility of the vitamins $[29,31]$. Thiamin $\left(B_{1}\right)$, and riboflavin $\left(B_{2}\right)$, for example, had increased bioaccessibility, with vine spinach $<$ amaranth $<$ spider plant $<$ cowpeas $<$ pumpkin leaves for $\mathrm{B}_{1}$, and pumpkin leaves, cowpeas amaranth spider plant, vine spinach for $\mathrm{B}_{2}$. These findings, therefore, may suggest other dynamics that led to the variation of vitamins in vegetables following both thermal processing and in vitro digestion [30, 43]. However, the difference in fiber content in the vegetables may not be significant to determine the changes. The variation in the bioaccessible levels found in this study partly arises from the difference in the alteration of the vegetable matrix, and in particular, vitamins are destroyed during cooking which then decreases their bioaccessible levels $[28,29]$. Further, the physicochemical properties of the vitamin have also been used to support the bioaccessible levels of vitamins $[26,27]$. 
TABle 2: Mean levels of vitamin B series and the percent change in fresh and processed LAIVs.

\begin{tabular}{|c|c|c|c|c|c|c|c|}
\hline \multirow[b]{2}{*}{ LAIVs } & \multirow[b]{2}{*}{ Fresh/processed } & \multicolumn{6}{|c|}{ Mean $( \pm \mathrm{SD}, n=3)$ levels $(\mathrm{mg} / 100 \mathrm{~g} \mathrm{DW})$ of vitamin B series (\% change on processing) } \\
\hline & & $\mathrm{B}_{1}$ & $\mathrm{~B}_{2}$ & $\mathrm{~B}_{3}$ & $\mathrm{~B}_{5}$ & $\mathrm{~B}_{6}$ & $\mathrm{~B}_{9}$ \\
\hline \multirow{5}{*}{$\begin{array}{l}\text { Spider } \\
\text { plant }\end{array}$} & Fresh & $3.12 \pm 0.06^{\mathrm{a}}$ & $127.64 \pm 9.70^{\mathrm{b}}$ & $107.70 \pm 1.80^{\mathrm{c}}$ & $9.98 \pm 0.06^{\mathrm{d}}$ & $5.88 \pm 0.03^{c}$ & $0.73 \pm 0.01^{\mathrm{d}}$ \\
\hline & Boiled & $\begin{array}{l}5.48 \pm 0.11^{\mathrm{b}} \\
(+75.64)\end{array}$ & $\begin{array}{c}73.19 \pm 5.70^{\mathrm{a}} \\
(-42.66)\end{array}$ & $\begin{array}{l}125.13 \pm 1.55^{\mathrm{d}} \\
\quad(+16.18)\end{array}$ & $5.45 \pm 0.16^{\mathrm{b}}(-45.39)$ & $\begin{array}{c}6.96 \pm 0.01^{\mathrm{d}} \\
(+18.37)\end{array}$ & $\begin{array}{c}0.42 \pm 0.01^{\mathrm{c}} \\
(-49.32)\end{array}$ \\
\hline & Boiled-fried & $\begin{array}{c}16.41 \pm 1.00^{c} \\
(+425.96)\end{array}$ & ND $(-100.00)$ & $\begin{array}{l}40.16 \pm 1.40^{\mathrm{a}} \\
\quad(-62.71)\end{array}$ & $2.92 \pm 0.11^{\mathrm{a}}(-70.74)$ & $\begin{array}{c}2.59 \pm 0.39^{\mathrm{b}} \\
(-55.95)\end{array}$ & $\begin{array}{c}0.33 \pm 0.01^{\mathrm{b}} \\
(-54.79)\end{array}$ \\
\hline & Dried & $\begin{array}{c}2.26 \pm 0.08^{\mathrm{a}} \\
(-27.56)\end{array}$ & ND $(-100.0)$ & $\begin{array}{c}87.52 \pm 2.54^{\mathrm{b}} \\
(-18.74)\end{array}$ & $6.82 \pm 0.27^{\mathrm{c}}(-31.66)$ & $\begin{array}{c}1.31 \pm 0.43^{\mathrm{a}} \\
(-77.72)\end{array}$ & $\begin{array}{c}0.20 \pm 0.00^{\mathrm{a}} \\
(-72.60)\end{array}$ \\
\hline & $p$ value & $<0.001$ & $<0.001$ & $<0.001$ & $<0.001$ & $<0.001$ & $<0.001$ \\
\hline \multirow{5}{*}{ Cowpeas } & Fresh & $2.90 \pm 0.09^{\mathrm{b}}$ & $60.83 \pm 1.58^{\mathrm{b}}$ & $24.51 \pm 1.22^{\mathrm{b}}$ & $9.45 \pm 0.20^{\mathrm{a}}$ & $3.60 \pm 0.04^{\mathrm{a}}$ & $20.68 \pm 0.12^{c}$ \\
\hline & Boiled & $\begin{array}{l}2.44 \pm 0.10^{\mathrm{a}} \\
(-15.86)\end{array}$ & $\begin{array}{c}1.30 \pm 0.05^{\mathrm{a}} \\
(-97.86)\end{array}$ & $\begin{array}{c}95.66 \pm 2.23^{c} \\
(+290.29)\end{array}$ & $\begin{array}{c}24.56 \pm 0.50^{\mathrm{b}} \\
(+159.89)\end{array}$ & $\begin{array}{c}14.72 \pm 0.51^{\mathrm{b}} \\
(+308.89)\end{array}$ & $\begin{array}{c}0.36 \pm 0.01^{\mathrm{a}} \\
(-98.26)\end{array}$ \\
\hline & Boiled-fried & ND $(-100.00)$ & $\begin{array}{c}1.69 \pm 0.02^{\mathrm{a}} \\
(-97.22)\end{array}$ & ND $(-100.00)$ & $33.56 \pm 0.90^{c}+225.13$ & $\begin{array}{c}16.20 \pm 0.06^{\mathrm{c}} \\
(+350.00)\end{array}$ & $\begin{array}{c}7.54 \pm 0.02^{\mathrm{b}} \\
(-63.53)\end{array}$ \\
\hline & Dried & ND $(-100.00)$ & ND $(-100.00)$ & $\begin{array}{c}10.67 \pm 0.99^{\mathrm{a}} \\
(-56.47)\end{array}$ & ND $(-100.00)$ & $\begin{array}{c}3.37 \pm 0.34^{\mathrm{a}} \\
(-6.39)\end{array}$ & $\begin{array}{c}19.39 \pm 1.60^{c} \\
(-6.24)\end{array}$ \\
\hline & $p$ value & $<0.001$ & $<0.001$ & $<0.001$ & $<0.001$ & $<0.001$ & $<0.001$ \\
\hline \multirow{5}{*}{ Amaranth } & Fresh & $3.76 \pm 0.11^{\mathrm{a}}$ & $79.73 \pm 5.41^{c}$ & $10.36 \pm 0.87^{b}$ & $11.18 \pm 0.24^{\mathrm{b}}$ & $83.10 \pm 0.92^{\mathrm{d}}$ & $1.70 \pm 0.02^{\mathrm{a}}$ \\
\hline & Boiled & $\begin{array}{l}8.63 \pm 0.05^{\mathrm{c}} \\
(+129.52)\end{array}$ & $\begin{array}{c}6.03 \pm 0.18^{\mathrm{a}} \\
(-92.44)\end{array}$ & ND $(-100.00)$ & $5.12 \pm 0.70^{\mathrm{a}}(-54.20)$ & $\begin{array}{c}21.18 \pm 0.94^{\mathrm{b}} \\
(-74.51)\end{array}$ & $\begin{array}{c}8.86 \pm 0.12^{c} \\
(+421.18)\end{array}$ \\
\hline & Boiled-fried & $\begin{array}{c}4.60 \pm 0.58^{\mathrm{b}} \\
(+22.34)\end{array}$ & $\begin{array}{c}6.31 \pm 0.38^{\mathrm{a}} \\
(-92.09)\end{array}$ & ND $(-100.00)$ & $\begin{array}{c}46.69 \pm 1.50^{c} \\
(+317.63)\end{array}$ & $\begin{array}{c}25.18 \pm 0.40^{c} \\
(-69.70)\end{array}$ & $\begin{array}{c}3.71 \pm 0.01^{b} \\
(+118.24)\end{array}$ \\
\hline & Dried & ND $(-100.00)$ & $\begin{array}{c}23.91 \pm 1.45^{\mathrm{b}} \\
(-70.01)\end{array}$ & $\begin{array}{c}8.81 \pm 0.66^{\mathrm{a}} \\
(-14.96)\end{array}$ & ND $(-100.00)$ & $\begin{array}{c}2.49 \pm 0.13^{\mathrm{a}} \\
(-97.00)\end{array}$ & ND $(-100.00)$ \\
\hline & $p$ value & $<0.001$ & $<0.001$ & $<0.001$ & $<0.001$ & $<0.001$ & $<0.001$ \\
\hline \multirow{5}{*}{$\begin{array}{l}\text { Vine } \\
\text { spinach }\end{array}$} & Fresh & $0.83 \pm 0.01^{\mathrm{b}}$ & $174.16 \pm 3.50^{\mathrm{d}}$ & $23.25 \pm 2.12^{\mathrm{b}}$ & $13.52 \pm 0.51^{\mathrm{c}}$ & $5.97 \pm 0.10^{\mathrm{b}}$ & $3.71 \pm 0.09^{\mathrm{a}}$ \\
\hline & Boiled & $\begin{array}{l}1.07 \pm 0.04^{\mathrm{c}} \\
(+28.92)\end{array}$ & $\begin{array}{c}1.35 \pm 0.03^{\mathrm{a}} \\
(-99.22)\end{array}$ & $\begin{array}{l}127.14 \pm 2.79^{\mathrm{d}} \\
(+446.84)\end{array}$ & $13.46 \pm 0.66^{\mathrm{c}}(-0.44)$ & $\begin{array}{c}18.68 \pm 0.30^{c} \\
(+212.09)\end{array}$ & ND $(-100.00)$ \\
\hline & Boiled-fried & ND $(-100.00)$ & $\begin{array}{l}18.45 \pm 0.50^{\mathrm{b}} \\
\quad(-89.40)\end{array}$ & $\begin{array}{l}36.61 \pm 2.20^{c} \\
(+57.46)\end{array}$ & $4.49 \pm 0.07^{\mathrm{a}}(-66.79)$ & $\begin{array}{c}2.85 \pm 0.06^{\mathrm{a}} \\
(-52.26)\end{array}$ & ND $(-100.00)$ \\
\hline & Dried & $\begin{array}{l}0.78 \pm 0.01^{\mathrm{a}} \\
\quad(-6.02)\end{array}$ & $\begin{array}{l}48.93 \pm 3.68^{\mathrm{c}} \\
\quad(-71.92)\end{array}$ & $\begin{array}{c}14.66 \pm 0.28^{\mathrm{a}} \\
(-36.95)\end{array}$ & $7.96 \pm 0.09^{\mathrm{b}}(-41.12)$ & ND $(-100.00)$ & ND $(-100.00)$ \\
\hline & $p$ value & $<0.001$ & $<0.001$ & $<0.001$ & $<0.001$ & $<0.001$ & $<0.001$ \\
\hline \multirow{5}{*}{$\begin{array}{l}\text { Pumpkin } \\
\text { leaves }\end{array}$} & Fresh & $4.56 \pm 0.04^{\mathrm{c}}$ & $35.44 \pm 0.72^{c}$ & $40.40 \pm 3.49^{\mathrm{b}}$ & $14.00 \pm 0.15^{\mathrm{a}}$ & $8.62 \pm 0.10^{c}$ & $2.46 \pm 0.03^{\mathrm{c}}$ \\
\hline & Boiled & $\begin{array}{c}3.72 \pm 0.06^{\mathrm{b}} \\
(-18.42)\end{array}$ & $\begin{array}{c}0.86 \pm 0.04^{\mathrm{a}} \\
(-97.57)\end{array}$ & $\begin{array}{c}43.92 \pm 2.62^{\mathrm{b}} \\
(+8.71)\end{array}$ & $\begin{array}{c}20.75 \pm 1.51^{\mathrm{b}} \\
(+48.21)\end{array}$ & $\begin{array}{c}0.63 \pm 0.01^{\mathrm{a}} \\
(-92.69)\end{array}$ & $\begin{array}{c}1.35 \pm 0.03^{\mathrm{b}} \\
(-45.12)\end{array}$ \\
\hline & Boiled-fried & $\begin{array}{c}10.26 \pm 0.80^{\mathrm{d}} \\
(+125.00)\end{array}$ & ND $(-100.00)$ & $\begin{array}{c}26.49 \pm 2.10^{\mathrm{a}} \\
\quad(-34.43)\end{array}$ & $\begin{array}{c}45.84 \pm 2.00^{\mathrm{c}} \\
(+227.43)\end{array}$ & $\begin{array}{l}7.24 \pm 0.48^{\mathrm{b}} \\
(-16.01)\end{array}$ & $\begin{array}{l}3.47 \pm 0.20^{\mathrm{d}} \\
(+41.06)\end{array}$ \\
\hline & Dried & $\begin{array}{c}3.71 \pm 0.01^{\mathrm{a}} \\
(-18.64)\end{array}$ & $\begin{array}{c}13.34 \pm 1.01 b \\
(-62.36)\end{array}$ & ND $(-100.00)$ & ND $(-100.00)$ & ND $(-100.00)$ & $\begin{array}{c}0.98 \pm 0.11^{\mathrm{a}} \\
(-60.16)\end{array}$ \\
\hline & $p$ value & $<0.001$ & $<0.001$ & $<0.001$ & $<0.001$ & $<0.001$ & $<0.001$ \\
\hline
\end{tabular}

Mean values followed by the same letters (superscript) within the same column of individual vegetables are not significantly different (SNK, $\alpha=0.05)$ ND- not detected.

TABle 3: Mean bioaccessible levels of vitamin B series in fresh and processed LAIVs and the percent change with in vitro digestion.

\begin{tabular}{|c|c|c|c|c|c|c|c|}
\hline \multirow[b]{2}{*}{ LAIVs } & \multirow[b]{2}{*}{ Fresh/processed } & \multicolumn{6}{|c|}{ Mean $( \pm \mathrm{SD}, n=3)$ bioaccessible levels ( $\mathrm{mg} / 100 \mathrm{~g} \mathrm{DW})$ of vitamin B series (\% change on processing) } \\
\hline & & $\mathrm{B}_{1}$ & $\mathrm{~B}_{2}$ & $\mathrm{~B}_{3}$ & $\mathrm{~B}_{5}$ & $\mathrm{~B}_{6}$ & $\mathrm{~B}_{9}$ \\
\hline \multirow{4}{*}{$\begin{array}{l}\text { Spider } \\
\text { plant }\end{array}$} & Fresh & $\begin{array}{c}0.89 \pm 0.10^{\mathrm{a}} \\
(28.61)\end{array}$ & $\begin{array}{c}126.75 \pm 9.77^{\mathrm{b}} \\
(99.30)\end{array}$ & $\begin{array}{c}105.62 \pm 1.86^{\mathrm{b}} \\
(98.07)\end{array}$ & $\begin{array}{c}0.43 \pm 0.02^{\mathrm{a}} \\
\quad(4.38)\end{array}$ & $\begin{array}{c}5.24 \pm 0.03^{\mathrm{b}} \\
(89.10)\end{array}$ & $\begin{array}{c}0.73 \pm 0.0^{c} \\
(100.00)\end{array}$ \\
\hline & Boiled & $\begin{array}{c}0.39 \pm 0.06^{\mathrm{a}} \\
(7.08)\end{array}$ & $\begin{array}{c}72.48 \pm 5.65^{\mathrm{a}} \\
(99.30)\end{array}$ & $\begin{array}{c}125.13 \pm 1.55^{\mathrm{c}} \\
(100.00)\end{array}$ & $\begin{array}{c}2.04 \pm 0.26^{\mathrm{b}} \\
(37.35)\end{array}$ & $\begin{array}{c}1.21 \pm 0.25^{\mathrm{a}} \\
\quad(12.30)\end{array}$ & $\begin{array}{c}0.23 \pm 0.01^{\mathrm{b}} \\
\quad(55.04)\end{array}$ \\
\hline & Boiled-fried & $\begin{array}{c}16.13 \pm 1.09^{\mathrm{b}} \\
(98.27)\end{array}$ & ND & $\begin{array}{c}38.70 \pm 1.55^{\mathrm{a}} \\
(96.34)\end{array}$ & $\begin{array}{c}0.60 \pm 0.12^{\mathrm{a}} \\
(22.89)\end{array}$ & $\begin{array}{c}1.15 \pm 0.37^{\mathrm{a}} \\
(39.78)\end{array}$ & $\begin{array}{c}0.19 \pm 0.01^{\mathrm{a}} \\
(55.80)\end{array}$ \\
\hline & $p$ value & $<0.001$ & $<0.001$ & $<0.001$ & $<0.001$ & $<0.001$ & $<0.001$ \\
\hline
\end{tabular}


TABle 3: Continued.

\begin{tabular}{|c|c|c|c|c|c|c|c|}
\hline \multirow[b]{2}{*}{ LAIVs } & \multirow[b]{2}{*}{ Fresh/processed } & \multicolumn{6}{|c|}{ Mean $( \pm \mathrm{SD}, n=3)$ bioaccessible levels $(\mathrm{mg} / 100 \mathrm{~g} \mathrm{DW})$ of vitamin B series (\% change on processing) } \\
\hline & & $\mathrm{B}_{1}$ & $\mathrm{~B}_{2}$ & $\mathrm{~B}_{3}$ & $\mathrm{~B}_{5}$ & $\mathrm{~B}_{6}$ & $\mathrm{~B}_{9}$ \\
\hline \multirow{4}{*}{ Cowpeas } & Fresh & $\begin{array}{c}2.49 \pm 0.09^{\mathrm{b}} \\
(85.88)\end{array}$ & $\begin{array}{c}60.83 \pm 1.58^{\mathrm{b}} \\
(100.00)\end{array}$ & $\begin{array}{c}24.51 \pm 1.22^{\mathrm{a}} \\
(100.00)\end{array}$ & $\begin{array}{c}1.18 \pm 0.21^{\mathrm{a}} \\
(11.63)\end{array}$ & $\begin{array}{c}2.12 \pm 0.11^{\mathrm{a}} \\
(61.88)\end{array}$ & $\begin{array}{c}20.68 \pm 0.12^{\mathrm{c}} \\
(100.00)\end{array}$ \\
\hline & Boiled & $\begin{array}{c}0.42 \pm 0.04^{\mathrm{a}} \\
(17.20)\end{array}$ & $\begin{array}{c}1.30 \pm 0.05^{\mathrm{a}} \\
(100.00)\end{array}$ & $\begin{array}{c}95.66 \pm 2.22^{\mathrm{b}} \\
(100.00)\end{array}$ & $\begin{array}{c}0.99 \pm 0.56^{\mathrm{a}} \\
(5.18)\end{array}$ & $\begin{array}{c}16.50 \pm 3.14^{\mathrm{b}} \\
(100.00)\end{array}$ & $\begin{array}{c}0.24 \pm 0.01^{\mathrm{a}} \\
(66.87)\end{array}$ \\
\hline & Boiled-fried & ND & $\begin{array}{c}1.60 \pm 0.03^{\mathrm{a}} \\
(94.74)\end{array}$ & ND & $\begin{array}{c}15.64 \pm 0.99^{\mathrm{b}} \\
(46.57)\end{array}$ & $47.23 \pm 0.86^{\mathrm{c}}$ & $7.54 \pm 0.20^{\mathrm{b}}$ \\
\hline & $p$ value & $<0.001$ & $<0.001$ & $<0.001$ & $<0.001$ & $<0.001$ & $<0.001$ \\
\hline \multirow{5}{*}{ Amaranth } & Fresh & $\begin{array}{c}0.77 \pm 0.04^{\mathrm{a}} \\
(20.62)\end{array}$ & $\begin{array}{c}79.73 \pm 5.41^{\mathrm{b}} \\
(100.00)\end{array}$ & $\begin{array}{c}6.93 \pm 0.64^{\mathrm{a}} \\
(63.25)\end{array}$ & $\begin{array}{c}12.72 \pm 1.82^{\mathrm{a}} \\
(34.53)\end{array}$ & $\begin{array}{c}75.23 \pm 1.39^{c} \\
(90.63)\end{array}$ & $\begin{array}{c}3.71 \pm 0.14^{\mathrm{b}} \\
(61.80)\end{array}$ \\
\hline & Boiled & $\begin{array}{c}1.99 \pm 0.01^{\mathrm{b}} \\
(23.00)\end{array}$ & $\begin{array}{c}3.70 \pm 0.25^{\mathrm{a}} \\
(61.41)\end{array}$ & ND & $\begin{array}{c}10.36 \pm 0.64^{\mathrm{a}} \\
(18.15)\end{array}$ & $\begin{array}{c}16.33 \pm 0.88^{\mathrm{a}} \\
(75.21)\end{array}$ & $\begin{array}{c}8.86 \pm 0.12^{\mathrm{c}} \\
(100.00)\end{array}$ \\
\hline & & $3.67 \pm 0.15^{\mathrm{c}}$ & $2.73 \pm 0.29^{\mathrm{a}}$ & & $15.64 \pm 0.99^{b}$ & $24.16 \pm 3.14^{\mathrm{b}}$ & $3.66 \pm 0.12^{\mathrm{a}}$ \\
\hline & Boiled-fried & (85.55) & $(43.17)$ & $\mathrm{ND}$ & $(46.57)$ & (95.83) & (98.72) \\
\hline & $p$ value & $<0.001$ & $<0.001$ & $<0.001$ & $<0.006$ & $<0.006$ & $<0.006$ \\
\hline \multirow{4}{*}{$\begin{array}{l}\text { Vine } \\
\text { spinach }\end{array}$} & Fresh & $\begin{array}{c}0.27 \pm 0.01^{b} \\
(32.31)\end{array}$ & $\begin{array}{c}174.12 \pm 3.57^{\mathrm{c}} \\
(99.98)\end{array}$ & $\begin{array}{c}6.93 \pm 0.64^{\mathrm{a}} \\
(98.50)\end{array}$ & $\begin{array}{c}2.82 \pm 0.60^{\mathrm{b}} \\
(22.94)\end{array}$ & $\begin{array}{c}5.00 \pm 0.30^{\mathrm{b}} \\
(83.66)\end{array}$ & $\begin{array}{c}3.17 \pm 0.10^{\mathrm{a}} \\
(100.00)\end{array}$ \\
\hline & Boiled & $\begin{array}{c}0.19 \pm 0.00^{\mathrm{a}} \\
(18.09)\end{array}$ & $\begin{array}{c}1.35 \pm 0.03^{\mathrm{a}} \\
(100.00)\end{array}$ & $\begin{array}{c}127.14 \pm 7.79^{\mathrm{c}} \\
(100.00)\end{array}$ & $\begin{array}{c}1.50 \pm 0.17^{\mathrm{a}} \\
(9.12)\end{array}$ & $\begin{array}{c}17.50 \pm 0.33^{c} \\
(93.67)\end{array}$ & ND \\
\hline & Boiled-fried & ND & $\begin{array}{c}18.17 \pm 0.55^{\mathrm{b}} \\
(98.49)\end{array}$ & $\begin{array}{c}36.22 \pm 2.29^{\mathrm{b}} \\
(98.94)\end{array}$ & $\begin{array}{c}0.64 \pm 0.17^{\mathrm{a}} \\
(14.23)\end{array}$ & $\begin{array}{l}2.71 \pm 0.06^{\mathrm{a}} \\
\quad(94.86)\end{array}$ & ND \\
\hline & $p$ value & $<0.001$ & $<0.001$ & $<0.001$ & $<0.004$ & $<0.004$ & $<0.004$ \\
\hline \multirow{5}{*}{$\begin{array}{l}\text { Pumpkin } \\
\text { leaves }\end{array}$} & Fresh & $\begin{array}{c}3.06 \pm 0.09^{\mathrm{b}} \\
(67.22)\end{array}$ & $\begin{array}{c}34.67 \pm 0.72^{\mathrm{b}} \\
(97.82)\end{array}$ & $\begin{array}{c}40.40 \pm 3.49^{\mathrm{b}} \\
(100.00)\end{array}$ & $\begin{array}{c}0.93 \pm 0.38^{\mathrm{a}} \\
(5.17)\end{array}$ & $\begin{array}{c}1.58 \pm 0.01^{\mathrm{b}} \\
(59.45)\end{array}$ & $\begin{array}{c}2.24 \pm 0.04^{\mathrm{b}} \\
(90.87)\end{array}$ \\
\hline & Boiled & $\begin{array}{c}2.04 \pm 0.18^{\mathrm{a}} \\
(54.94)\end{array}$ & $\begin{array}{c}0.19 \pm 0.01^{\mathrm{a}} \\
(22.28)\end{array}$ & $\begin{array}{c}37.27 \pm 4.71^{\mathrm{b}} \\
(100.00)\end{array}$ & $\begin{array}{c}4.75 \pm 2.35^{\mathrm{b}} \\
(16.97)\end{array}$ & $\begin{array}{c}0.63 \pm 0.01^{\mathrm{a}} \\
(100.00)\end{array}$ & $\begin{array}{c}0.95 \pm 0.03^{\mathrm{a}} \\
(70.81)\end{array}$ \\
\hline & Bo & $9.74 \pm 0.84^{c}$ & ND & $24.87 \pm 2.13^{\mathrm{a}}$ & $25.51 \pm 2.79^{c}$ & $3.86 \pm 0.05^{\mathrm{c}}$ & $2.98 \pm 0.30^{c}$ \\
\hline & Bo & (95.02) & $\Gamma$ & (93.85) & $(55.58)$ & $(100.00)$ & $(85.79)$ \\
\hline & $p$ value & $<0.001$ & $<0.001$ & $<0.001$ & $<0.001$ & $<0.001$ & $<0.001$ \\
\hline
\end{tabular}

Mean values followed by the same letters of the same vegetable within the same column are not significantly different $(\mathrm{SNK}, \alpha=0.05)$.

\section{Conclusion}

The levels of vitamin $\mathrm{B}$ series $\left(\mathrm{B}_{1}, \mathrm{~B}_{2}, \mathrm{~B}_{3}, \mathrm{~B}_{5}, \mathrm{~B}_{6}\right.$, and $\left.\mathrm{B}_{9}\right)$ in Cleome gynandra, Vigna unguiculata, Amaranthus viridis, Basella alba, and Cucurbita maxima were affected by processing, with most reduction experienced in dried samples. Boiling and boiled-frying processes resulted in both increases and decreases in the bioaccessible levels of the vitamins. The changes in the bioaccessible levels did not reflect the changes in the fiber content of the vegetables. The levels in both the fresh and processed vegetables and further their in vitro bioaccessible levels are sufficient to meet the WHO recommended dietary allowances (RDA) levels for children and adults. These findings can be used to promote the nutritional approach to address malnutrition.

\section{Data Availability}

The data used to support the findings of the study have been deposited within the article.

\section{Conflicts of Interest}

The authors declare that there are no conflicts of interest regarding the publication of this article.

\section{Acknowledgments}

The authors acknowledge the African Development Bank (Ref. No. I84/32244/2015) and National Research Fund, Kenya (Grant No. NRF/Ph.D./02/55), for the funding, the University of Eldoret for the in-kind support to undertake the study, Jomo Kenyatta University of Agriculture and Technology for laboratory facilities and collaborating institutions, Kenyatta University, and the United States International University, Africa.

\section{References}

[1] G. C. Bwembya, J. M. Thwala, and D. A. Otieno, "Vitamin A and resources; mineral content of some common vegetables consumed in Swaziland," UNISWA Journal of Agriculture Science and Technology, vol. 15, pp. 9-18, 2014.

[2] I. I. Nkafamiya, S. A. Oseameahon, U. U. Modibbo, and D. Haggai, "Vitamins and effect of blanching on nutritional and antinutritional values of non-conventional leafy vegetables," African Journal of Food Science, vol. 4, pp. 335-341, 2010.

[3] F. Agyemang-Yeboah and S. Y. Oppong, "B-vitamins role in cellular metabolism and clinical nutrition," Tropical Series in Health Science, vol. 1, pp. 39-49, 2013. 
[4] WHO, The World Health Organization 2002-Reducing Risks, Promoting Healthy Life, World Health Organization, Geneva, Switzerland, 2002.

[5] WHO, "Diet nutrition and the prevention of chronic diseases. report of joint FAO/WHO expert consultation," World Health Organization, Geneva, Switzerland, 916, 2003.

[6] WHO, The World Health Report 1998, The World Health Organization, Geneva, Switzerland, 1998.

[7] UNICEF/WHO, "The world bank. joint child malnutrition estimate- levels and trends," Global Database on Child Growth and Malnutrition, World Health Organization, Geneva, Switzerland, 2014.

[8] G. Schellack, P. Harirari, and N. Schellack, "B-complex vitamin deficiency and supplementation," South African Pharmaceutical Journal, vol. 83, pp. 28-32, 2015.

[9] M. P. Nawiri, H. Nyambaka, and J. I. Murungi, "Sun-dried cowpeas and amaranth leaves recipe improves $\beta$-carotene and retinol levels in serum and hemoglobin concentration among preschool children," European Journal of Nutrition, vol. 52, no. 2, pp. 583-589, 2013.

[10] M. K. Alam, S. Sams, M. S. Khan et al., "Profiling of minerals, water soluble vitamins and carotenoid in selected unconventional leafy and non-leafy vegetables of Bangladesh," Natural Product Research, pp. 1-5, 2020.

[11] M. Abukutsa-Onyango, "The cultivated African leafy vegetables in three communities in western Kenya," Journal of Food Agriculture, and Development, vol. 3, pp. 85-91, 2007.

[12] S. W. Kebede and W. Bokelmann, "African indigenous vegetables and their production practices: evident from the HORTINLEA survey in Kenya," Agrotechnology, vol. 6, pp. 2168-9881, 2017.

[13] A. M. Opiyo, N. W. Mungai, L. Nakhone, and J. K. Lagat, "Production status and impact of traditional leafy vegetables in household food security: a case study of Bondo districtSiaya county- Kenya," Asian Research Publshing Network (ARPN) Journal of Agricultural and Biological Science, vol. 10, pp. 330-338, 2015.

[14] M. Akbar, I. N. Sherazi, M. S. Lqbal, and H. M. Waqas, "Antibacterial and antioxidant activities of slender amaranth weed," Planta Daninha, vol. 38, p. 1, 2020.

[15] F. I. Smith and P. Eyzaguirre, "African leafy vegetables: their role in the world health organisation's global fruits and vegetables initiative," African Journal of Food Agriculture, Nutrition and Development, vol. 7, pp. 1684-5374, 2007.

[16] M. M. Croft, M. I. Marshall, and S. C. Weller, "Consumers' preference for quality in three African indigenous vegetables in western Kenya," Journal of Agricultural Economics and Development, vol. 3, pp. 67-77, 2014.

[17] S. A. Okewole, L. O. Oyekunle, and O. Akande, T. T. Adebisi and T. Olubode, Nutritional compositions of selected green leafy vegetables in Oyo state, Nigeria," Asian Journal of Applied Chemistry Research, vol. 1, pp. 1-7, 2018.

[18] A. D. T. Fabbri and G. A. Crosby, "A review of the impact of preparation and cooking on the nutritional quality of vegetables and legumes," International Journal of Gastronomy and Food Science, vol. 3, pp. 2-11, 2016.

[19] J. Wakhanu, H. Nyambaka, M. Nawiri, J. Kimiywe, and W. Thagana, Nutrition-sensitive intervention with African indigenous leafy vegetables among school-going children in Machakos county, Kenya," Journal of Medicinally Active Plants, vol. 9, pp. 111-125, 2020.

[20] C. Hotz and R. S. Gibson, "Traditional food-processing and preparation practices to enhance the bioavailability of micronutrients in plant-based diets," The Journal of Nutrition, vol. 137, no. 4, pp. 1097-1100, 2007.

[21] F. Ismail, F. N. Talpur, and A. N. Memon, "Determination of water soluble vitamin in fruits and vegetables marketed in sindh Pakistan," Pakistan Journal of Nutrition, vol. 12, no. 2, pp. 197-199, 2013.

[22] F. Okpalamma, P. C. Ojimelukwe, and E. A. Mazi, "Post harvest storage and processing changes in carotenoids and micronutrients in fluted pumpkin (telferia occidentalis Hook F.)," IOSR Journal of Agriculture and Veterinary Science, vol. 6, no. 4, pp. 34-39, 2013.

[23] T. Fukawatari and K. Shibata, "Relative availability of B-group vitamins in a diet to free vitamins in (Japanese)," Journal of Home Economics of Japan, vol. 59, pp. 403-410, 2008.

[24] V. Öhrvik, "Folate bioavailability," Thesis, Swedish University of Agricultural Sciences, Uppsala, Sweden, 2009.

[25] P. Etchiverry, M. A. Grusak, and L. E. Fleige, "Application of in vitro bioaccessibility and bioavailability methods for calcium, carotenoids, folate, iron, magnesium, polyphenols, zinc and vitamins $\mathrm{B}_{6}, \mathrm{~B}_{12}, \mathrm{D}$ and E," Frontiers in Physiology, vol. 3, pp. 317-321, 2012.

[26] M. L. Failla, T. Huo, and S. K. Thakkar, "In vitro screening of relative bioaccessibility of carotenoids from foods," Asia Pacific Journal of Clinical Nutrition, vol. 17, pp. 200-203, 2008.

[27] L. Yonekura and A. Nagao, "Intestinal absorption of dietary carotenoids," Molecular Nutrition \& Food Research, vol. 51, no. 1, pp. 107-115, 2007.

[28] B. Bua and C. Onang, "Validating the role of African indigenous vegetables for food and nutrition security in Uganda," Journal of Food Science and Engineering, vol. 7, pp. 316-322, 2017.

[29] A. Nagao, "Bioavailability of dietary carotenoids: intestinal absorption and metabolism," JARQ, vol. 48, pp. 383-391, 2014.

[30] H. Palafox-Carlos, J. F. Ayala-Zavala, and G. A. GonzálezAguilar, "The role of dietary fiber in the bioaccessibility and bioavailability of fruit and vegetable antioxidants," Journal of Food Science, vol. 76, no. 1, pp. R6-R15, 2011.

[31] S. Veda, A. Kamath, K. Platel, K. BegumPlatel, and K. Srinivasan, "Determination of bioaccessibility of $\beta$-carotene in vegetables by in vitro methods," Molecular Nutrition \& Food Research, vol. 50, no. 11, pp. 1047-1052, 2006.

[32] Z. M. Onyambu, M. P. Nawiri, H. N. Nyambaka, and N. M. Naumih, "In vitro bioaccessibility of beta carotene from thermally processed leafy African indigenous vegetables," Journal of Kenya Chemical Society, vol. 14, pp. 3-8, 2021.

[33] J. Parada and J. M. Aguilera, "Food microstructure affects the bioavailability of several nutrients," Journal of Food Science, vol. 72, pp. 1701-1710, 2007.

[34] N. Cheruiyot, "Determination of levels of some vitamins in Amaranthushypochondriacus and Amaranthus cruenthus leaves and grains from selected areas of Kenya," MSc. thesis, Kenyatta University, Nairobi, Kenya, 2011.

[35] A. Jedicka and J. Klimes, Determination of Water- and FatSoluble Vitamins in Different Matrices using High-Performance Liquid Chromatography, Department of Pharmaceutical Chemistry and Drug Control, Charles University, Prague, Czechia, 2004.

[36] A. Taylor, S. Branch, M. Day, and M. White, "Atomic spectrometry update," Journal of Analytical Atomic Spectrometry, vol. 21, pp. 114-121, 2006.

[37] R. Ekinci and C. Kadakal, "Determination of seven watersoluble vitamins in tarhana, a traditional Turkish cereal food 
by high performance liquid chromatography," ACTA Chromatographica, vol. 15, pp. 289-300, 2005.

[38] W. Sawyer and A. Beebe, Chemistry Experiment for Instrumental Methods, John Wiley and Sons, Hoboken, NJ, USA, 2007.

[39] N. N. Ahamed, M. Saleemullah, H. U. Shah, I. A. Khalil, and A. U. R. Saljoqi, "Determination of beta carotene content in fresh vegetables using high-performance liquid chromatography," Sarhad Journal of Agriculture, vol. 23, pp. 767-770, 2007.

[40] M. N. Hasan, M. Akhtaruzzaman, and M. Z. Sultan, "Estimation of vitamins B-complex (B2, B3, B5 and B6) of some leafy vegetables indigenous to Bangladesh by HPLC method," Journal of Analytical Sciences, Methods and Instrumentation, vol. 3, pp. 24-29, 2013.

[41] A. J. Uraku, A. O. Oko, H. N. Onuigbo et al., "Determination of some vitamins in three selected African green leafy vegetables," International Journal of Pharmacy and Medical Sciences, vol. 5, pp. 22-26, 2015.

[42] C. Kunyanga, J. Imungi, and V. Vellingiri, "Nutritional evaluation of indigenous foods with potential food-based solution to alleviate hunger and malnutrition in Kenya," Journal of Applied Biosciences, vol. 67, pp. 5277-5288, 2013.

[43] L. Montagne, J. R. Pluske, and D. J. Hampson, "A review of interactions between dietary fibre and the intestinal mucosa, and their consequences on digestive health in young nonruminant animals," Animal Feed Science and Technology, vol. 108, no. 1-4, pp. 95-117, 2003.

[44] D. Enyiukwu, A. C. Amadioha, A. Amadioha, and C. Ononuju, "Nutritional significance of cowpea leaves for human consumption," Greener Trends in Food Science and Nutrition, vol. 1, no. 1, pp. 1-10, 2018.

[45] M. Lymio, "Identification and nutrient composition of indigenous vegetables in Tanzania," Plant Foods for Human Nutrition, vol. 58, pp. 85-92, 2003.

[46] A. R. Vicente, G. A. Manganaris, G. O. Sozzi, and C. H. Crisosto, "Nutritional quality of fruits and vegetables," Postharvest Handling. A Systems Approach, Elsevier Academic Press, Cambridge, MA, USA, 2nd edition, 2009. 